\title{
Gridhrasi and Its Management through Panchakarma- A Case Study
}

\author{
Pooja Jaiswal ${ }^{1}$, Pradeep Jane ${ }^{2}$ \\ ${ }^{1}$ P G Scholar, Panchakarma Department, R. A. PodarAyu Medical College, Worli Mumbai- 18, Maharashtra, India \\ ${ }^{2}$ Professor and HOD of Panchakarma Department, R. A. PodarAyu Medical College, Worli Mumbai- 18, Maharashtra, India
}

\begin{abstract}
In this hectic life sciatic pain is a very common disorder that hampers people from doing their routine activities. Most of people suffering from this, complains about moderate to severe pain in buttock region which then radiate to thigh, calf and down to the foot and even toes. The main cause of sciatica can be a horizontal or slipped disc, piriformis syndrome, spinal stenosis, spondylolisthesis. In the starting stage people neglect this but later this becomes a major issue when the pain becomes unbearable. Classics of Ayurveda have references related sciatica, according to Ayurveda signs and symptoms of sciatica is much similar to "Grdhrasi-VaataRoga." Grdhrasi can be treated remarkably with procedures of panchakarma and internal medications. Here in the case study a female patientpresenting with clinical features of sciatica and MRI findings suggesting of disc bulge and prolapse at the level of lumbar vertebrae was given Panchakarmatreatment. The patient was treated with classical treatments like Kati Bast,and Kala Basti with certain conventional oral medication. The results of the study are highlyencouraging.
\end{abstract}

Keywords: Gridhrasi, KalaBasti, katibasti

\section{Introduction}

Gridhrasi (Sciatica) is one among 80 types of NanatmajaVatavyadhi.It is a disorder in which low back pain is found, that spreads through the hip, to the back of the thigh and down the inside of the leg. There are many causes for low back pain, however true sciatica is a symptom of inflammation or compression of the sciatica nerve. The sciatica nerve carries impulses between nerve roots in the lower back and the muscles and nerve of the buttocks, thighs and lower legs. Compression of a nerve root often occurs as a result of damage to one of the discs between the vertebrae. In some cases, sciatic pain radiate from other nerves in the body. This is called referred pain. Pain associated with sciatica often is severe, sharp and shooting. It may be accompanied by other symptom, such as numbness, tingling, weakness and sensitivity to touch.

Although low back pain is a common condition that affects as many as $80-90 \%$ of people during their lifetime, true sciatica occurs in about $5 \%$ of cases. Sciatica is more common between 30 and 50 years of age [1].

Pain in sciatica is very severe, which makes the patient difficult to walk; hampering the daily routine of the individual. No satisfactory treatment available in modern medical science, patients depends on pain killers which has temporary action.

Basti is the most important among panchkarma due to its multiple effects. Pitta and kapha are dependent on vata as it governs their functions. Basti is not only best for vata disorder but also equally effective in correcting the morbid pitta , kapha, rakta.(2) Charak has considered ,Bastitherpy as half of the treatment of all the disease, while some autors consider it as the complete remedy for all the ailments.(3)

\section{Case Report}

A female patient aged 42 yearspresented with the complaint of low back ache with dragging pain radiating to left limb associated with numbness and tinglingsensation since lyears. But from 15 days patient increase the severityof symptoms.

\section{Observations}

- Signs: -Tendernessin lumbosacral area. SLR test was positive. Lasagne's sign was positive.

- Symptoms: -Dragging type of pain radiating from lower back region to leftlimb, associated with numbness, tingling sensation and heaviness of the limb.

- MRI report: -

1) Lessthan Grade-1 anterior listhesis of L5 over S1 due to bilateral isthmic defect in pars interarticularies. Straightening of lumbar curvature with severe degenerative changes at L5-S1.

2) Pseudo protrusion of central, para central and lateral hard disc at L5-S1 causing mild reduction ofcentral canal dimension andforaminal impingement upon exiting both L5 nerve root.

3) Degenerative focal soft tissue canal stenosis at L3-4 and L4-5.

4) Mild facetal hypertrophy added with small symmetric para central disc bulge at L2-3 and right paracentral hard disc protrusion at L1-2 causing mild indentation upon right half of ventral thecal sac.

- Gait: - Slow, dragging slight twisting the left foot.

- Prakriti: - Vata-Pitta.

- Bala: - Madhyama

- Agni: - - Madhyama

- Koshta: - Madhyama

\section{Treatment Given}

Kati Basti (Topical application of medicated oil): The procedure of applying heat to the sacral or lumbar region byretaining warm medicated oil with in aspecially formed frame onthis area isknown as Kati Basti. It is indicated 


\section{International Journal of Science and Research (IJSR) \\ ISSN (Online): 2319-7064 \\ Index Copernicus Value (2015): 78.96 | Impact Factor (2015): 6.391}

inpainful condition of low back region. [4]The procedure was done with BalaashwagandhaTailamfor 30 minutes forduration of 16 days.

\section{Basti Karma (Therapeutic enema):}

NiruhaBasti (Decoction enema): The composition of the medicineadministered in the form of Basticontains Kwath (herbal decoction), Sneha(medicated oil), Madhu(Honey), SaindhavaLavana(rocksalt) and Kalka (herbal powder).[5]

DashmoolKwathaNiruhaBastiwas given in Kala

Bastischedule (16 days) with the following contents.

- Madhu -60gms

- Saindhavalavana -05 gms

- Guggulutiktakaghrita -90ml

- Shatapushpa Kalka -30gms

- Dashmoolkwatha $-240 \mathrm{ml}$

Drugs of Dashmool decoction:

Shalparni (Desmodium gangeticum), Prashniparni (Urariapicta), Kantakari (Solanum surattenese), Bruhati (Solanum indicum), Gokshura (Tribulusterrestris), Bilva (Aegle marmelos), Agnimanth (Premnaintegrifolia), Sonapaatha (Oroxylumarborea), Paatala (Sterospermumsuaveoleus) and Gambhari (Gmelinaarborea).

AnuvasanaBasti: - Administration of medicated oil or other fat through the rectal route in a prescribed dose is called as AnuvasanaBasti. In this case study DashmoolaTaila was used for anuvasanabasti.

ShamanaAushadi: - Palliative treatment with

YograjaGuggulu- 2 pills (500 mgm) three times a day.

RasnaSaptakaKwath $-40 \mathrm{ml}+$ DashmoolKwath $-40 \mathrm{ml}$ two times a day

Ksheerabala 101 times Avartita-10 drops with milk two times a day.

PanchasakaraChurna - 5gms at bed time.

\section{The results observed after the treatmentwere:}

Improvement in signs and symptoms of the patient. Relief was found in dragging pain, numbness and tingling sensation. Gait has improved.

- Walking distance:-

Before treatment: - Patient had severe pain after walking 100 mts.

After treatment: - Patient could easily walk without pain about 200 mts.

- Walking time:-

Before treatment: - Patient took around five minutes to walk 100 steps.

After treatment: patient took around three minutes to walk 100 steps.

No significant change was observed in MRI REPORT

\section{Discussion}

The Bulging and prolapse of disc causes obstruction to the movement of Vataresulting in VataPrakopa. Bastiis the best treatment for correcting VataDosha.
By virtue of the drugs of DashmoolKwathaNiruhaBastithe Avaranaof Vatamay be reduced which in turn makes the free movement of Vatawhich may be reason for reduction in pain, numbness etc. and improvement in gait. Specially GugguluTiktakaGhritamused as Sneha in Bastiis specifically mentioned for AsthiSandhigataVikara due to its Tikta Rasa helps to reachAsthi Sandhi and corrects the degeneration that took place at the level of disc by virtue of Snigdhaguna and Balya and Brimhanaaction.

Kati Bastiis a combination of Snehana and Svedana which is the first line of treatment for VataDosha. The BalaAshwagandhaTaila is Brimhanaand Snehanain nature helps to overcome theaccumulation of Vata at the site of pathology and may nourish the underlying tissue.

Shamana drugs: - MainlyAmapachana, Shothaharamedicines which reduces the Shotha and AvartitaKsheeraBalaTaila is Brimhana and Vataharamight have helped to overcome degeneration of disc and VataPrakopa.

\section{Conclusion}

On the basis of this single case study it can be concluded that Panchakarma treatments like Kati BastiDASHMOOL NiruhaBasti had been effective in the management of Gridhrasi(sciatica)

\section{References}

[1] Stanley J. Swierzewski, Remedy Health Media. Sciatica Overview; www.healthcommunities.com

[2] (2)SushrutasushrutaSamhitawithnibandhasarasangraha commentary of Sri Dalhana Acharya and Nyaya Chandrika panjika of Sri Gayadasacharya; edited by VadiyaYadavjiTrikamji Acharya and Narayan ram Acharya; Reprinted edition, 2003; Krishnadas Academy, Varanasi.Uttar Pradesh 6th ed, 1997, p 255,268,420-421

[3] Agnivesha:CharakSmhita with Ayurveda DeepikaTeekha by Chakarpani Dutta Published by Chakhambasanskritasansthan, Varansi ,fifth edition 1992 p689

[4] Dr.G.Shrinivasa Acharya, Panchakarmalllustrated, first edition 2006, Choukhambha Sanskrit Pratishthan, Delhi, ISBN-81,7084-3079,pg.254.

[5] Dr.G.Shrinivasa Acharya, Panchakarma Illustrated, first edition 2006, Choukhambha Sanskrit Pratishthan, Delhi, ISBN-81,7084-3079 pg.382 